DOI: $10.24045 / \mathrm{pp} .2017 .2 .9$

\title{
PECULIARITIES OF PATHOGENESIS OF COMORBID ARTERIAL HYPERTENSION AND DIABETES MELLITUS 2 TYPE
}

\author{
O. M. Bilovol \\ L. R. Bobronnikova
}

\author{
Doctor of Medical Sciences, professor, Academician \\ of the National Academy \\ of Sciences of Ukraine \\ Doctor of Medical Sciences, professor \\ Kharkov National Medical University \\ Kharkiv, Ukraine
}

\begin{abstract}
In the article features of pathogenetic mechanisms of the combined course of arterial hypertension and type 2 diabetes mellitus are considered. This pathology potentiates the development of micro- and macrovascular complications, raises cardiovascular risk. Concomitant abdominal obesity contributes to the imbalance of adipocytokines, and complicates the course of type 2 diabetes. It was established that polymorphism of candidate genes associated with the development and progression of insulin resistance, which is of interest for further study.
\end{abstract}

Keywords: arterial hypertension; diabetes mellitus type 2; pathogenesis mechanisms of development; adipokines imbalance; gene polymorphism.

The comorbidity of arterial hypertension (AH) and type 2 diabetes mellitus (DM) is a serious problem, which is associated with an earlier development of target organ lesions and subsequent cardiovascular accidents [25].

The most important role in the pathogenesis of BP is played by the reninangiotensin-aldosterone system (RAAS), which, according to a number of studies, is divided into circulating and local. Directly local RAAS is involved in the formation of a characterized for DM syndrome of hyperinemic hypotokosteronism in which low concentration of aldosterone in plasma is combined with a high concentration of circulating angiotensin II (AT II) [11, 16]. The hypodynamy development is caused by high activity of local renal AT II, which concentration is by 1000 times higher than the concentration of circulating [13]. In addition to the kidneys, such a high activity of local RAAS was found in DM in the heart and in the vascular endothelium. Excessive formation of AT II in the kidneys leads to intra-cerebral hypertension, then to sclerosis and fibrosis of the renal tissue, to the remodeling of the myocardium in the heart, promotes the development of atherosclerosis in the vessels [11]. Thus, the disruption of the functioning of local RAAS in DM leads to the development of $\mathrm{AH}$, which is also included by and characteristic of DM -the increase in the sensitivity of vessels to constrictive influences [17]. Recent studies have shown that the hyperactivity of RAAS plays an important role in the development of insulin resistance (IR), which may lead to DM type 2 [11]. This is illustrated by the fact 
that the inhibitor of the angiotensinconverting enzyme (ACEI) leads to a decrease in IR and may be accompanied by the development of hypoglycemic conditions [12]. With the help of modern molecular biological technologies, it has been established that post-receptor signaling systems of AT II and insulin are closely related. AT II blocks one of the key insulin enzymes (PI3-K), which takes part in the transport of glucose to cells, the synthesis of NO, and at the same time, activates other enzymes responsible for mitogenic and proliferative processes in the vascular wall [10]. The components of local RAAS are found both in the exocrine ducts and in the b-cells of the pancreatic islets [9]. This made it possible to explain the blocking effect of AT II on the secretion of insulin and the enhancement of peripheral tissue TI with its excessive secretion. Hyperglycemia is the main metabolic sign of DM type 2, but insulin secretion begins long before the diagnosis establishing - even with a pre-diabetes glycemia level. The probability of fatal and nonfatal cardiovascular complications increases significantly not only with an obvious disease, but also at the pre-diabetes stage. Already at the stage of impaired glucose tolerance (IGT), the incidence of coronary artery disease and atherosclerosis is significantly higher than in normoglycemia [1]. Annually about $10-12 \%$ of people with IGT have development of DM type 2, and fasting glycemia more than $5.6 \mathrm{mmol} / \mathrm{l}$ increases the risk of transition of IGT to DM type 2 by 3.3 times [2]. Based on the results of the prospective clinical study Heart Outcomes Prevention Evaluation, there is a correlation between the level of HbA1c and the relative risk of complications, using the sex and age of the surveyed, and it was also found that chronic hyperglycemia is a risk factor for cardiovascular disease in patients with DM type 2. IR is a key link in the pathogenesis of DM type 2, atherosclerosis, $\mathrm{AH}$, syndrome of sclerocystic ovaries and other diseases. IR is an independent risk factor for the development of dyslipidemia, systemic inflammation and oxidative stress [4]. The published outputs of clinical and experimental studies indicate that IR causes an impairment of the physiological mechanisms of vasodilation. The effect of insulin on the endothelium of the vascular wall is mediated by its own receptors and is realized through a multistage signaling system associated with an increase in the synthesis of nitric oxide (NO). In patients with $\mathrm{AH}$ and concomitant DM 2 type, under conditions of IR, the endothelium-dependent vasodilation induced by NO is significantly reduced [13]. Some studies indicate that hyperinsulinemia correlates with other risk factors, such as increased body mass index (BMI), obesity of the abdominal type, hypertension, increased triglyceride levels, and cardiovascular disease [20].

Numerous indicates that interleukin imbalance in patients with $\mathrm{AH}$ and DM type 2 is more associated with increased risks of cardiometabolic complications. The list of known interleukins continues to grow from year to year: pro-inflammatory interleukins (IL-1, IL-2, IL-6, IL-1 $\beta$, IL-12), pro inflammatory (IL-4, IL-10, IL-13) determination of their role in the pathogenesis development of type DM 2 diabetes and $\mathrm{AH}[10]$.

It is believed that as a result of the cascade activity of pro-inflammatory cytokines, observes fat accumulation in adipocytes, liver, muscles, $\beta$-cells of the pancreas simultaneously with increased lipolysis and the development of adipocyte IR [13].

According to the results of the Framingham study, it was found that even after adjusting the age, smoking, BP and total cholesterol (TC) levels in the blood, the presence of DM increases the risk of coronary heart disease (CHD) in men by $66 \%$, in women by $23 \%$ [6]. A study on risk stratification in pa-

Paradigmata poznání. 2. 2017 
tients with $\mathrm{AH}$ and DM type 2, conducted in Ukraine, showed that almost half of patients with DM type 2 and uncontrolled $\mathrm{AH}$ have a very high 4-year risk of cardiovascular complications that are characterized by elevated BP $\mathrm{c}$ and the presence of concomitant pathological changes. In experimental and clinical studies it was indicated that the presence of DM type 2 adversely affects myocardial function, even in the absence of coronary atheromatous lesions. Cardiac disorders in DM type 2 proceed in the form of CI and subclinical disorders of myocardial contractility. These studies may it possible suggest that DM type 2 is the cause of the development of specific cardiomyopathy [8]. In particular a number of scientists have indicated that with DM type 2 is observed diffuse lesions and myocardial hypertrophy, as well as disorders of its contractility [9]. Other scientists consider the fact that the main sign of myocardial infarction in DM type 2 is the development of cardiomyopathy with a decrease in the rate of diastolic myocardial relaxation [10].

In the report of the experts of the National Cholesterol Education Program in the USA [5], patients with DM type 2 with a risk of developing complications and, accordingly, in the strategy of lipid-lowering therapy are equated with patients who have IHD. This provision is included in the European recommendations for the prevention of cardiovascular disease [6].

The assessment of risk factors for CHD in diabetes mellitus was carried out in UKPDS (United Kingdom prospective diabetes study), the largest prospective observation in the area of DM type 2. After adjusting the data for sex and age, it was found that the risk factors for CHD in diabetes are (in order of importance) an increase in the level of low-density lipoprotein cholesterol (LDL-C), increased BP, smoking, low-density lipopro-

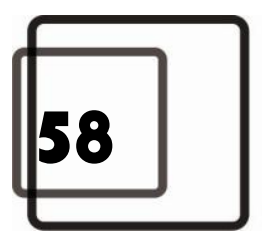

tein cholesterol (HDL-C), an increase in HbA1c level [30].

Comorbidity of arterial hypertension and type 2 diabetes mellitus in the structure of the metabolic syndrome.

$\mathrm{AH}$ and $\mathrm{CD} 2$ are components of the metabolic syndrome (MS), so often occur against a background of obesity [13]. Data from epidemiological studies indicate that the overwhelming majority of patients with type 2 diabetes are overweight or obese. Thus, with type I obesity, the risk of DM type 2 increases by 2 times, grade II obesity -5 times, and grade III obesity - more than 10 times.

It is well known that the fat tissue of a person is divided into brown and white adipose tissue, each of which is endowed with certain functions. Brown fat tissue is identified in the cervical, supraclavicular, axillary and paravertebral area in adults and is the main depot of thermogenesis and energy expenditure [15]. All processes of the lipolysis regulation in it are carried out under the influence of the sympathetic nervous system, through the activation of $\beta$ adrenergic receptors and the signaling pathways. Currently, white fatty tissue is considered as an endocrine organ that synthesizes a large number of adipose tissue hormones - adipokines and biologically active substances, the majority of which disrupt the transmission of the insulin signal and cause IR. It is the main storage place for excess energy derived from food. The white adipose tissue is further divided, according to the distribution in the organism, into the visceral adipose tissue and the subcutaneous adipose tissue [22]. The studies have shown that abdominal visceral fat deposition is associated with impaired glucose tolerance and IR, regardless of body weight [19]. Recently, the search for new adipocytokines and their metabolic effects, the main theme in the study of obesity. It is known that all adi- 
pokines have the own individual effects on metabolic processes in the organism There is an increased secretion of biologically active peptides and hormones has been established in visceral adipose tissue, that enhance IR, such as tumor necrosis factor- $\alpha$ (TNF- $\alpha$ ), resistin, retinol-binding protein-4 (RSP-4), visfatin, IL -6 and others, but simultaneously excretion of hormones adiponectin, omentine, glypican-3, which reduce the manifestations of IR [13].

The influence of genetic polymorphism on the development and progression of insulin resistance.

There are two ways of development in the formation of IR: hereditary and acquired [23]. Data from clinical and experimental studies demonstrate that one of the key factors in the development and progression of IR is the genetic single-nucleotide polymorphism of a various candidate genes [11]. The references data say that the sensitivity of peripheral tissues to insulin is determined by the presence of specific receptors (IRS-1, IRS-2) mediating the stimulating effect of insulin on the utilization of glucose by glucose transporters and triggering a range of cellular responses. At the present stage, it has been proved that the polymorphism of IRS-1, IRS2 and other genes responsible for the synthesis of protein molecules involved in the transduction of the biological signal of insulin is accompanied by a different degree of expression of receptor resistance [9]. It was established that the polymorphism of the insulin receptor - IRS-2, is associated with the development of IR [13].

In studies of several authors, it has been established that the receptor for sulfonylureas, which is encoded by this gene on the $11 \mathrm{p} 15.1$ chromosome, is a component of the ATPdependent potassium ion transport channel. This channel regulates the secretion of insulin $\beta$-cells by changing the membrane potential. The consequence of these processes is a decrease in the membrane potential, an increase in the intake of calcium ions inside the cell, that increases the secretion of granules with insulin. Another group of scientists established a protein gene linking the mRNA of insulin-like growth factor 2 (IGF2BP2). A family of genes that bind insulin-like growth factor mRNA include six proteins, some of which show a high affinity for insulin-like growth factors 1 and 2 (IGF-1, 2). In a number of studies, it has been established that the product of the IGF2BP2 gene forms a complex with the mRNA of the IGF2 gene and affects the increase in insulin levels, 2:00 after taking a glucose tolerance test (GTT), and also contributes to a decrease in HOMA-IR [5].

The involvement of polymorphism of adipokine genes in the development of IR is actively studied. Thus, it has been established that the single -nucleotide substitution of T45G (rs2241766) in the second exon of the adiponectin gene (AdipoQ) is associated with IR, impaired glucose tolerance, and high levels of lipoproteins and total cholesterol in blood [25]. Inactivated receptors of mice for adiponectin (AdipoR1 and AdipoR2) were indicated as having an increase in triglyceride levels and development of inflammation and oxidative stress. This led to a state of IR and an immunity to an increase in glucose concentration [18]. In a singlecase clinical and experimental studies was established the association of the IR development with the carrier of the genotype R-223R of the receptor gene to leptin, the G$75 \mathrm{G}$ genotype of the apolipoprotein $\mathrm{A} 1$ gene, and the presence of certain polymorphic variants of the resistin gene of the C-180C genotype [10].

Considering the multicomponent nature of genetic disorders that lead to the formation of IR, complex and multifactorial studies of the genetic nature of IR are necessary, taking into account the effects of environmental factors such as high-calorie nutrition and low physical activity that contributes to the

Paradigmata poznání. 2. 2017 
maximum manifestation of genetic predisposition to IR in the phenotype [12].

Conclusions. It has been established that the pathogenic mechanisms contribute to the development of $\mathrm{AH}, \mathrm{IR}$, and DM type 2 are often coincide and lead to the progression of diseases and the development of complications. Concomitant obesity, in patients with $\mathrm{AH}$ and DM type 2, is a factor in the progression of metabolic disorders, IR, activation of markers of immune inflammation and atherogenesis. In return, visceral obesity contributes to an imbalance in the production of adipocytokines, which leads to a chain of pathophysiological disorders in the organism. The imbalance of adipocytokines aggravates the course of DM type 2 and contributes to deterioration in the parameters of carbohydrate metabolism. The development of IR is characterized by polygenic nature, caused by polymorphism of genes. There are more than 20 candidate genes for IR, among those genes is involved in the regulation of glucose metabolism, lipids, and also the genes of adipose tissue hormones. Thus, a comprehensive approach to the study of genetic predictors in the formation of combined AH and DM type 2 , and immediately IR, may contribute to the selection of more precise therapeutic tactics in patients with $\mathrm{AH}$ and DM type 2.

\section{Bibliography}

1. Королюк О. Я., Радченко О. М. Прогностичне значення критеріїв метаболічного синдрому у хворих на IXC із вперше виявленою гіперглікемією // Практикуючий лікар. - 2013. - № 4 С. $46-50$.

2. Цукровий діабет, предіабет і серцево-судинні захворювання: Методичні рекомендації Робочої групи Асоціації кардіологів України та Асоціації ендокринологів України з метаболічного синдрому, діабету, предіабету і серцевосудинних захворювань. - К. : Асоціація кардіологів України, 2014. - 40 с.

3. Arikoglu H., Ozdemir H., Kaya D. E. The Adiponectin variants contribute to the genetic back- ground of type 2 diabetes in Turkish population. 2014. -Vol. 534. - P. 10-16.

4. Cai R., Yuan Y., Sun J., Xia W., Huang R. Statins worsen glycemic control of T2DM in target LDLc level and LDL-c reduction dependent manners: a meta-analysis // Expert Opin, Pharmacother. 2016. - Aug. - P. 4.

5. Cha S. A., Yun J. S., Lim T. S. Hypoglycemia and Cardiovascular or All-Cause Mortality in Patients with Type 2 Diabetes //Diabetes Metab. J. - 2016. - Jun. - Vol. 40 (3). - P. 202-210.

6. Chung H-F., Long K. Z., Hsu C-C. Adiponectin gene (AdipoQ) polymorphisms correlate with the progression of nephropathy in Taiwanese male patients with type 2 diabetes // Diabetes research and clinical practice. - 2014. -Vol. 105(2). P. 261-270.

7. Charvát J. What is the significance of the phenomenon of hypertension in disguise in patients with type 2 diabetes mellitus treated for long-lasting hypertension? // Vnitr. Lek. - 2016. Mar. - Vol. 62(3). - P. 215-217.

8. Gui M-H., Li X., Jiang S-F. Association of the adiponectin gene rs1501299 G>T variant, serum adiponectin levels, and the risk of coronary artery disease in a Chinese population // Diabetes research and clinical practice. - 2012. Vol. 97(3). - P. 499-504.

9. Gerstein H. C., Pogue J. The relationship between dysglycaemia and cardiovascular and renal risk in diabetic and non-diabetic participants in the HOPE study: a prospective epidemiological analysis // Diabetologia. - 2005. -Vol. 48(9). P. 1749-1755.

10. Hanis C. L., Redline S., Cade B.E. Beyond type 2 diabetes, obesity and hypertension: an axis including sleep apnea, left ventricular hypertrophy, endothelial dysfunction, and aortic stiffness among Mexican Americans in Starr County, Texas // Cardiovasc. Diabetol. - 2016. Jun. - Vol. 8(15). - P. 86.

11. Horr S., Nissen S. Managing hypertension in type 2 diabetes mellitus /// Best Pract Res. Clin. Endocrinol. Metab.- 2016. - Jun. - Vol. 30(3). P. 445-454.

12. Khalyfa A., Mutskov V., Carreras A., Khalyfa A. A., Hakim F., Gozal D. Sleep fragmentation during late gestation induces metabolic perturbations and epigenetic changes in adiponectin gene expression in male adult offspring mice // Diabetes. - 2014. - Vol. 63(3230). - P. 41.

13. Leroith D. Pathophysiology of the metabolic syndrome: implications for the cardiometabolic 
risks associated with type 2 diabetes // Am. J. Med. Sci. - 2012. - Jan. -Vol. 3 (1). - P. 13-16.

14. Mather K. J., Christophi C. A., Jablonski K. A. Common variants in genes encoding adiponectin (ADIPOQ) and its receptors (ADIPOR1/2), adiponectin concentrations, and diabetes incidence in the Diabetes Prevention Program // Diabetic medicine. - 2012. - Vol. 29(12). - P. 1579-1588.

15. Mohammedi K., Woodward M,. Hirakawa Y. Microvascular and Macrovascular Disease and Risk for Major Peripheral Arterial Disease in Patients With Type 2 Diabetes // Diabetes Care. 2016. - Jul. - P. 26-30.

16. Nasser M. R. Association of Adiponectin Gene Polymorphism (bT45G) With Acute Coronary Syndrome and Circulating Adiponectin Levels // Angiology. - 2012. - Vol. 64(4). - P. 257-265.

17. Nibouche W. N., Biad A. Arterial hypertension at the time of diagnosis of type 2 diabetes in adults / Ann. Cardiol. Angeiol, Paris. - 2016. - Jun. Vol. 65(3). - P. 152-158.

18. Oliveira C.S.V., Saddi-Rosa P., Crispim F. Association of ADIPOQ variants, total and high molecular weight adiponectin levels with coronary artery disease in diabetic and non-diabetic // Brazilian subjects. Journal of diabetes and its complications. - 2012. - Vol. 26(2). - P. 94-98.

19. Okada-Iwabu M., Yamuchi T., Iwabu M. A small-molecule AdipoR agonist for type 2 diabetes and short life in obesity // Nature. - 2013. Vol. 50. - P. 493-499.

20. Razavian N., Blecker S., Schmidt A.M. Prediction of Type 2 Diabetes From Claims Data and Analysis of Risk Factors // Big Data. - 2015. Dec. - Vol. 3(4). - P. 277-287.

21. Ren J., Anversa P. The insulin-like growth factor I system: physiological and pathophysiological implication in cardiovascular diseases associated with metabolic syndrome // Biochem. Pharmacol. 2015. - Feb. - Vol. 93(4). - P. 409-417.

22. Savanelli M. C., Scarano E., Muscogiuri G. Cardiovascular risk in adult hypopituitaric patients with growth hormone deficiency: is there a role for vitamin D? // Endocrine. - 2016. Apr. - Vol. 52(1). - P. 111-119.
23. Skau J. K., Nordin A. B., Cheah J. C. A complex behavioural change intervention to reduce the risk 2 diabetes and prediabetes in the pre-conception period in Malaysia: study protocol for a randomised controlled trial // Trials. -2016. Apr. - Vol. 17(1). - P. 215.

24. Stöckl D., Rückert-Eheberg I. M., Heier M. Regional Variability of Lifestyle Factors and Hypertension with Prediabetes and Newly Diagnosed Type 2 Diabetes Mellitus: The Population-Based KORA-F4 and SHIP-TREND Studies in Germany // PLoSOne. - 2016. - Jun. P. 11.

25. Sang H. C., Ji W. B., Eun S. K. Gender Diferences in Hypertension Control Among Older Korean Adults: Korean Social Life, Health, and Aging Project // J. Prev. Med. Public. Health. 2015. - Vol. 48.- P. 20.

26. Takhshid M. A., Haem Z., Aboualizadeh F. The association of circulating adiponectin and 45T/G polymorphism of adiponectin gene with gestational diabetes mellitus in Iranian population // J. Diabet. Metab. Disord. - 2015. - Vol. 14. - P. 30.

27. Ramya K., Ayyappa K.A., Ghosh S. Genetic association of ADIPOQ gene variants with type 2 diabetes, obesity and serum adiponectin levels in south Indian population // Gene. - 2013. Vol. 532. - P. 253-262.

28. Tu Y., Yu Q. L., Fan G. R. Assessment of type 2 diabetes risk conferred by SNPs rs2241766 and rs1501299 in the ADIPOQ gene, a case/control study combined with meta-analyses // Mol .Cell. Endocrinol. - 2014. - Vol. 396. - P. 1-9.

29. Wijkman M., Länne T., Östgren C. J. Diastolic orthostatic hypertension and cardiovascular prognosis in type 2 diabetes: a prospective cohort study // Cardiovasc. Diabetol. - 2016. - Jun. Vol. 15. - P. 83.

30. Yaghootkar H., Lotta L. A. Tyrrell J.Genetic Evidence for a Link Between Favorable Adiposity and Lower Risk of Type 2 Diabetes, Hypertension, and Heart Disease // Diabetes. 2016. - Aug. - Vol. 65(8). - P. 2448-2460.

(C) Bilovol O. M., Bobronnikova L. R., 2017. 